\title{
Moringa oleifera Seed Actions Following Aspartame Consumption: A Systematic Evaluation of the Large Intestine
}

Mbadugha Christopher Chiedozie ${ }^{1 *}$, Edem Gabriel Donatus ${ }^{1}$, Shakirat Yetunde Amoo-Tella ${ }^{2}$, Uwakmfon-Abasi Ime Enang $^{1}$

\author{
${ }^{1}$ Department of Anatomy, Faculty of Basic Medical Sciences, University of Uyo, P.M.B. 1017, Uyo, Akwa Ibom State, Nigeria \\ ${ }^{2}$ Department of Anatomy, Faculty of Medical Sciences, College of Medicine, Umaru Musa Yar'adua University, Katsina State, Nigeria
}

DOI: $10.36348 /$ sijap.2022.v05i01.003 $\quad$ | Received: 13.12.2021 | Accepted: 16.01.2022 | Published: 28.01 .2022

*Corresponding author: Mbadugha Christopher Chiedozie

Department of Anatomy, Faculty of Basic Medical Sciences, University of Uyo, P.M.B. 1017, Uyo, Akwa Ibom State, Nigeria

\section{Abstract}

The study was carried out to assess the effect of oral administration of Moringa oleifera seed extract following aspartame consumption on the intestinal wall. Twenty-seven (27) rats were used for this study. They were divided into nine groups. Group A, the control group were administered distilled water, Group B were administered $0.4 \mathrm{ml}$ of Aspartame, Group C were administered $1.5 \mathrm{ml}$ of Aspartame, Group D1 were administered $0.6 \mathrm{ml}$ of aspartame for the first three weeks followed by $1.5 \mathrm{ml}$ of ethanolic extract of ground moringa seed on the fourth week, Group D2 was administered $0.5 \mathrm{ml}$ of aspartame for the first three week followed by $1.3 \mathrm{ml}$ of $\mathrm{n}$-Hexane extract of ground moringa seed on the fourth week, Group E1 were administered $1.3 \mathrm{ml}$ of apartame for the first three weeks, followed by $2.5 \mathrm{ml}$ of ethanolic extract of ground moringa seed on the fourth week, Group E2, were administered $1.5 \mathrm{ml}$ of aspartame for the first three weeks followed by $3.0 \mathrm{ml}$ of n-Hexane extract of ground moringa seed on the fourth week, Group F1 were administered 1.4 $\mathrm{ml}$ of aspartame and $2.8 \mathrm{ml}$ of ethanolic extract of ground moringa seed from week one to week four. Group F2 were administered 1.3 $\mathrm{ml}$ of aspartame and $2.5 \mathrm{ml}$ of $\mathrm{n}$-Hexane extract of ground moringa seed from week one to week four. The experiment lasted for 28 days. The rats were weighed once a week. On the $28^{\text {th }}$ day, the rats were anaesthetized via chloroform inhalation; the large intestine harvested and fixed in $10 \%$ buffered formalin, processed and stained with Harris Haematoxylin and Eosin (H\&E). Blood were harvested for analysis of Blood Glucose Level. Data were expressed as Mean \pm standard error of the Mean (M \pm SEM) and subjected to one-way analysis of variance. Significant difference between mean was accessed by Student-New-Man-Keuls post hoc test. $95 \%$ level of significance $(\mathrm{p}<0.05)$ was used for statistical analysis. Ethanolic extract of Moringa oleifera seed extract could not protect the Large intestine from the toxic effect of aspartame while the n-Hexane extract of Moringa oleifera seed has a protective effect on the large intestine.

Keywords: Moringa oleifera, Aspartame, Large intestine, Albino Wister rats, Ethanol, N-Hexane.

Copyright ( $) 2022$ The Author(s): This is an open-access article distributed under the terms of the Creative Commons Attribution 4.0 International License (CC BY-NC 4.0) which permits unrestricted use, distribution, and reproduction in any medium for non-commercial use provided the original author and source are credited.

\section{INTRODUCTION}

Aspartame is a dipeptide artificial sweetener widely used as a non-nutritive sweetener in food product (Rencuzogullari et al., 2004). It is also used as a sweetener in food products like dry beverages mixes, chewable multivitamins, breakfast cereals, chewable gums, pudding and fillings, carbonated beverages, refrigerated and non-refrigerated ready to drink beverages, yogurt type products and pharmaceutical (George et al., 2010). Aspartame is immediately absorbed from the intestinal lumen and metabolized to phenylalanine, aspartic acid and methanol. Hence, concentration of its metabolites is increased in the blood (Abhilash et al., 2013). Phenylalanine may cross the blood-brain-barrier and cause severe changes in production of very important neurotransmitter.
Methanol breaks down into formate which in turn is very cytotoxic and can cause blindness. Excessive aspartame ingestion is implicated in the pathogenesis of certain metabolic diseases, mental disorders and also in comprised learning and emotional functioning.

Moringa oleifera $L$. from the Moringaceae family is a perennial tree widely cultivated in many tropic regions and easily grown in adverse conditions. Moringa oleifera is commonly known as drumstick tree (due to slender, long-triangular seed pods), horse-radish tree (the roots taste similar to that of horse-radish), benoil tree (as the benzoil is extracted from the tree) (Raja et al., 2016). The plants are referred to as the "miracle tree" because of the enormous positive impact it has on people's livelihood. It is reported that every plant part (seed, flowers, stems, leaves and roots) is a 
great source of nutrients and produces major essential medicinal principles (Daba, 2016), curing a range of disease (Ganguly, 2013). For industrial uses, biodiesel and cosmetic oil can be extracted from the seeds. The seeds can also be used in water purification processes (Mofijur et al., 2014). Moringa oleifera pods and flowers have a high content of total monounsaturated fatty acids while the seeds and oil from the seeds possess a high content of Oleic and Palmitic acid (Mohammed et al., 2003).

Regular consumption of artificially sweetened soft drinks is associated with disorders of the metabolic syndrome, including abdominal disorders, obesity, insulin resistance and/or impaired glucose tolerance, dyslipidemia and high blood pressure (Nettleton et al., 2019). In particular, daily diet soda consumption (primarily sweetened with N-a-L-aspartyl-Lphenyalanine methyl ester, aspartame), is reported to increase the relative risk of type 2 diabetes and the metabolic syndrome by $67 \%$ and $36 \%$ respectively (Lutsey et al., 2018) as well as systemic inflammation.

Inflammatory bowel disease (IBD), including Ulcerative colitis (UC) and Crohn's disease (CD), is a chronic recurrent disease of the intestine ( $\mathrm{Ni}$ et al., 2017). IBD is exceptionally harmful and is associated with an increased risk for colon cancer (Nadeem et al., 2020). IBD is affected by diets such as high-fat diets, and the incidence is high during consumption of artificial sweetener. The pathogenesis of IBD is not yet fully clear; it is generally considered to be related to the environment, infection, genetics, psychology, and immunity. In addition, the intestinal mucosal immune system plays an essential role in the pathogenesis of IBD (Atreya et al., 2008). Several studies have shown that there is a high level of activated transcription factor kappa B in the intestinal mucosa of IBD patients, and nuclear transcription factor kappa $\mathrm{B}(\mathrm{NF}-\kappa \mathrm{B})$ is considered to be one of the most critical signaling pathways in IBD. High expression of NF- $\kappa \mathrm{B}$ can enhance the release of proinflammatory cytokines, such as tumor necrosis factor- $\alpha$ (TNF- $\alpha)$ and interleukin- 6 (IL-6), which leads to colonic tissue damage (Giner et al., 2011).

In the body, Aspartame is transformed into Phenylalanine (Phy), aspartic acid and methanol. These metabolites can affect the gastrointestinal state of the colon and influence the levels of gastrointestinal enzymes (Humphries et al., 2008).

Moringa oleifera is a widely used medicinal herb which has biochemical components such as tannins, sterols, terpenoids, flavonoids, saponins, anthraquinones, alkaloids and reducing sugar present along with anti-cancerous agents like glucosinolates (Berkovich et al., 2013). Due to its anti-spasmodic, anti-tumour, anti-epileptic, and anti-inflammatory properties which has been confirmed in the treatment of gastrointestinal disorders (Sharma et al., 2012), Moringa oleifera is being investigated in this research to ascertain its ameliorative effects on the large intestine of adult male albino Wister rats following Aspartame consumption.

\section{AIM OF THE STUDY}

The aim of this research was to investigate the effect of Moringa oleifera seed extract on the large intestine following Aspartame consumption in adult male Albino Wister rats. The specific objectives include:

i. To determine the effect of Moringa oleifera seed extracts on the histoarchitecture of the large intestine of adult male Albino Wister rats.

ii. To determine the effect of Moringa oleifera seed extract and Aspartame on the body weight of adult male Albino Wister rats.

iii. To evaluate the effects of the ethanolic extract of the Moringa oleifera seed extract on the histology of the large intestine of adult male Albino Wister rats following Aspartame administration.

iv. To evaluate the effect of n-Hexane extract of Moringa oleifera seed extract on the histology of the large intestine of adult male Albino Wister rats following Aspartame administration.

v. To determine the effects of Moringa oleifera seed extract on the blood glucose level of adult male Albino Wister rats following aspartame administration

\section{EXPERIMENTAL SECTION/MATERIALS AND METHODS}

Twenty-seven adult male Albino Wister rats with weight ranging from $133 \mathrm{~g}$ to $212 \mathrm{~g}$ were used for the study. They were fed pelletized grower mash and clean drinking water. They were kept in nine wooden cages, 18 inches by 12 inches in dimension; with wire gauze covers and saw dust as beddings, under standard room temperature. The animals were handled in compliance with applicable guidelines for the care and use of laboratory animals.

\section{PREPARATION OF MORINGA OLEIFERA AND ASPARTAME}

The Moringa oleifera pod was broken and the seeds removed and well ground using a manual grinder. The Soxhlet method of extraction was used. $80 \%$ of ethanol was added to $500 \mathrm{~g}$ of ground Moringa seed, $80 \%$ of $\mathrm{n}$-Hexane was added to $500 \mathrm{~g}$ of ground Moringa seed. Both extracts were gotten by filtration, stored in a glass beaker, covered with foil and placed in the fridge to preserve the efficacy of the Moringa oleifera seed extract. $1.0 \mathrm{~g}$ of aspartame was dissolve in $50 \mathrm{ml}$ distilled water. 
Mbadugha Christopher Chiedozie et al; Sch Int J Anat Physiol, Jan., 2022; 5(1): 15-24

\section{EXPERIMENTAL PROTOCOL}

Following two weeks acclimatization, the rats were divided into nine equal groups designated as $\mathrm{A}, \mathrm{B}$, C, D1, D2, E1, E2, F1, and F2; each group consisted of three animals. Group A the control group were administered distilled water, Group B were administered $0.4 \mathrm{ml}$ of aspartame, Group C were administered $1.5 \mathrm{ml}$ of aspartame, Group D1 were administered $0.6 \mathrm{ml}$ of aspartame for the first three weeks followed by $1.5 \mathrm{ml}$ of ethanolic extract of ground Moringa seed on the fourth week, Group D2 was administered $0.5 \mathrm{ml}$ of aspartame for the first three weeks followed by $1.3 \mathrm{ml}$ of $\mathrm{n}$-Hexane extract of ground Moringa seed on the fourth week, Group E1 were administered $1.3 \mathrm{ml}$ of aspartame for the first three weeks, followed by $2.5 \mathrm{ml}$ of ethanolic extract of ground Moringa seed on the fourth week, Group E2, were administered $1.5 \mathrm{ml}$ of aspartame for the first three weeks followed by $3.0 \mathrm{ml}$ of $\mathrm{n}$-Hexane extract of ground Moringa seed on the fourth week, Group F1 were administered $1.4 \mathrm{ml}$ of aspartame and $2.8 \mathrm{ml}$ of ethanolic extract of ground Moringa seed from week one to week four and Group F2 were administered 1.3 $\mathrm{ml}$ of aspartame and $2.5 \mathrm{ml}$ of $\mathrm{n}$-Hexane extract of ground Moringa seed from week one to week four.
The animals were anaesthetized with chloroform. The thoraco-abdominal wall of the animals was dissected to access the heart and blood was gotten directly from the heart. The rats were perfused with $1000 \mathrm{ml}$ of Normal saline to clear the blood impurities, followed by perfusion with $10 \%$ buffered formalin transcardially, to preserve the brain. The large intestine was harvested and fixed in 10\% buffered formalin for 48 hours.

The tissue processing procedure used involved: dehydration, clearing, infiltration, embedding, sectioning (microtomy), staining and mounting. The processed tissues were then subjected to microscopy. Data obtained from the study was expressed as mean \pm standard error of mean and were analysed using oneway analysis of variance (ANOVA).

\section{RESULTS AND DISCUSSION PHYTOCHEMICAL ANALYSIS OF MORINGA OLEIFERA}

The extract from the Moringa oleifera was screened for the presence of secondary metabolites using standard methods (Odebiyi and Sofowora, 1978). The result is shown in Table 1 .

Table 1: Phytochemical results

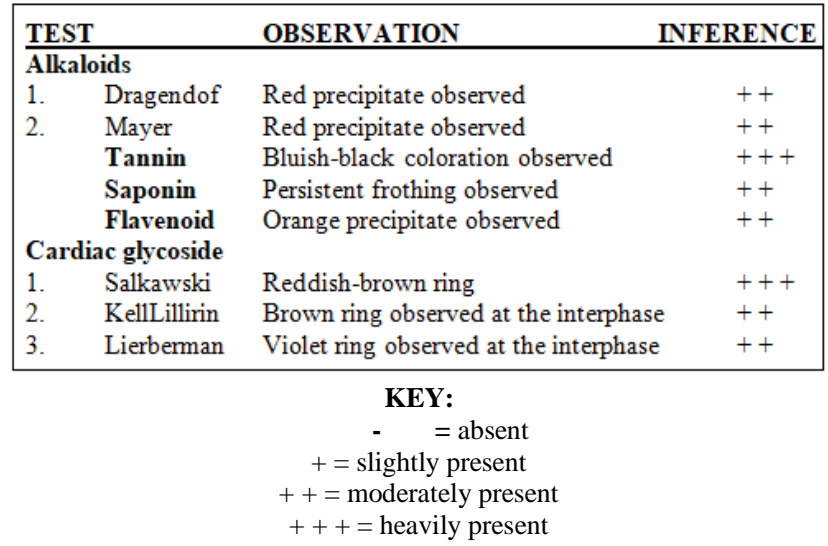

\section{Comparison of Changes in Body Weight of Adult Male Albino Wistar Rats}

The result of the changes in body weight following the administration of Aspartame and Moringa oleifera seed extract for twenty-eight days is shown in Table 2.

Table 2: Comparison of Changes in Body Weight of Adult Male Albino Wistar Rat in Grams (gm)

\begin{tabular}{|l|l|l|l|l|}
\hline Groups & Week 1 & Week 2 & Week 3 & Week 4 \\
\hline A & $205.50 \pm 6.50$ & $220.50 \pm 8.50$ & $313.00 \pm 8.00$ & $313.00 \pm 7.00$ \\
\hline B & $143.00 \pm 5.13$ & $144.50 \pm 5.50$ & $238.00 \pm 9.00$ & $242.00 \pm 10.00$ \\
\hline C & $182.33 \pm 1.20$ & $192.33 \pm 1.45$ & $288.00 \pm 3.21$ & $292.33 \pm 4.18$ \\
\hline D1 & $182.00 \pm 9.50$ & $188.67 \pm 10.68$ & $286.33 \pm 13.45$ & $289.00 \pm 14.01$ \\
\hline D2 & $151.67 \pm 1.20$ & $161.33 \pm 1.45$ & $254.67 \pm 4.67$ & $255.67 \pm 4.41$ \\
\hline E1 & $144.33 \pm 3.84$ & $155.67 \pm 2.33$ & $244.67 \pm 6.39$ & $245.33 \pm 7.31$ \\
\hline E2 & $174.67 \pm 4.98$ & $191.00 \pm 6.51$ & $282.67 \pm 6.94$ & $284.00 \pm 9.07$ \\
\hline F1 & $179.33 \pm 8.69$ & $197.00 \pm 10.82$ & $281.33 \pm 10.73$ & $276.67 \pm 8.97$ \\
\hline F2 & $154.67 \pm 4.81$ & $171.33 \pm 4.37$ & $253.00 \pm 3.51$ & $248.67 \pm 3.84$ \\
\hline
\end{tabular}

Values are expressed as mean \pm standard error of mean $(\mathrm{S} \pm \mathrm{SEM})$. At $95 \%$ level of significance $(\mathrm{P}<0.05)$ 
Mbadugha Christopher Chiedozie et al; Sch Int J Anat Physiol, Jan., 2022; 5(1): 15-24

Key:

$\mathrm{A}=$ rats given distilled water Group A (Control).

$\mathrm{B}=$ rats given $0.4 \mathrm{ml}$ (low dose) aspartame for four weeks (28 days)

$\mathrm{C}=$ rats given $1.5 \mathrm{ml}$ (high dose) aspartame for four weeks (28 days)

$\mathrm{D}_{1}=$ rats given $0.6 \mathrm{ml}$ (low dose) aspartame for the first 3 weeks and on the fourth week, $1.5 \mathrm{ml}$ (low dose) ethanolic seed extract of Moringa oleifera only.

$\mathrm{D}_{2}=$ rats given $0.5 \mathrm{ml}$ (low dose) aspartame for the first 3 weeks and on the fourth week, $1.3 \mathrm{ml}$ (low dose)nHexane seed extract of Moringa oleifera only.
$\mathrm{E}_{1}=$ rats given $1.3 \mathrm{ml}$ (high dose) aspartame for the first 3 weeks and on the fourth week, $2.5 \mathrm{ml}$ (high dose) ethanolic seed extract of Moringa oleifera only.

$\mathrm{E}_{2}=$ rats given $1.5 \mathrm{ml}$ (high dose) aspartame for the first 3 weeks and on the fourth week, $3.0 \mathrm{ml}$ (high dose)n-Hexane seed extract of Moringa oleifera only.

$\mathrm{F}_{1}=$ rats given $1.4 \mathrm{ml}$ (high Dose) aspartame followed by $2.8 \mathrm{ml}$ (high dose) ethanolic seed extract Moringa oleifera for four weeks.

$\mathrm{F}_{2}=$ rats given $1.3 \mathrm{ml}$ (high Dose) aspartame followed by $2.5 \mathrm{ml}$ (high dose) $\mathrm{n}$-Hexane seed extract Moringa oleifera for four weeks.

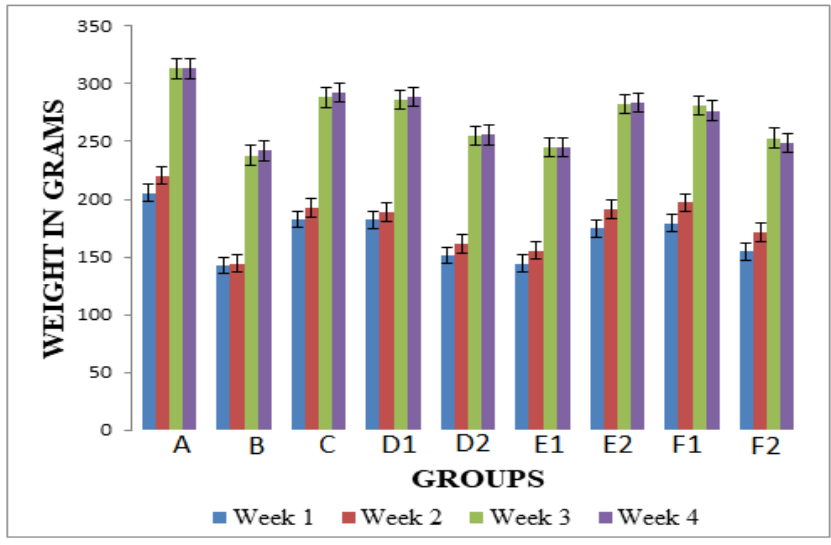

Figure 1: Comparison of changes in body weight of albino rats. (data are expressed in mean and standard error of mean, $\mathrm{M} \pm \mathrm{SEM}$ )

Blood glucose count for adult male Albino Wistar rats administered aspartame. This is shown in Table 3.

Table 3: Blood Glucose Count

\begin{tabular}{|l|l|l|}
\hline GROUP & ABO & CONC $(\mathbf{m m o l} / \mathbf{l})$ \\
\hline A & 0.27 & 3.7 \\
\hline A & 0.228 & 3.13 \\
\hline B & 0.068 & 0.94 \\
\hline B & 0.098 & 0.94 \\
\hline C & 0.24 & 3.29 \\
\hline C & 0.257 & 3.52 \\
\hline C & 0.352 & 4.82 \\
\hline D1 & 0.294 & 4.03 \\
\hline D1 & 0.095 & 1.3 \\
\hline D1 & 0.381 & 5.22 \\
\hline D2 & 0.581 & 7.95 \\
\hline D2 & 0.062 & 0.86 \\
\hline D2 & 0.045 & 0.06 \\
\hline E1 & 0.454 & 6.22 \\
\hline E1 & 0.342 & 4.69 \\
\hline E1 & 0.334 & 4.57 \\
\hline E2 & 0.744 & 10.19 \\
\hline E2 & 0.22 & 3.02 \\
\hline E2 & 0.388 & 5.32 \\
\hline F1 & 0.385 & 5.28 \\
\hline F1 & 0.206 & 2.83 \\
\hline F1 & 0.179 & 2.45 \\
\hline F2 & 0.234 & 3.21 \\
\hline F2 & 0.153 & 2.1 \\
\hline F2 & 0.456 & 6.24 \\
\hline & & \\
\hline
\end{tabular}


Mbadugha Christopher Chiedozie et al; Sch Int J Anat Physiol, Jan., 2022; 5(1): 15-24

\section{Hematoxylin and Eosin (H\&E) Method for General Demonstration of Large intestine \\ Cross section of the large intestine of rats} given distilled water, Group $\mathrm{A}(\mathrm{Control})$ viewed under the light microscope using magnification of X100 and X400 revealed normal histological appearance of the large intestine and features typical of a normal large intestine including absorptive columnar epithelium, goblet cells, lamina propria, muscularis mucosa, submucosa, muscularis externa, and serosa in Figure I and II.

Cross section of the large intestine of rats given $0.4 \mathrm{ml}$ (low dose) of aspartame, Group B revealed atrophy of absorptive columnar epithelium, atrophy of goblet cells, showed the intestinal wall was slightly affected in Figure III.

Cross section of the large intestine of rats given $1.5 \mathrm{ml}$ (high dose) of aspartame, Group C revealed atrophy of absorptive columnar epithelium, atrophy of goblet cells and intestinal glands, atrophy of lamina propria and muscualris mucosa, thus indicating a severe effect on the large intestine in Figure V.

Cross section of the large intestine of rats given $0.6 \mathrm{ml}$ (low dose) of aspartame for the first 3 weeks and on the fourth week, $1.5 \mathrm{ml}$ (low dose) ethanolic extract of Moringa oleifera seed revealed atrophy of absorptive columnar epithelium, inflammation of goblet cells and intestinal glands, atrophy of lamina propria and muscularis mucosa, thus indicating a severe effect on the intestinal wall in Figure VII.

Cross section of the large intestine of rats given $0.5 \mathrm{ml}$ (low dose) of aspartame for the first 3 weeks and on the fourth week, $1.3 \mathrm{ml}$ (low dose) of nHexane extract of Moringa oleifera seed revealed intact absorptive columnar epithelium, goblet cells, muscularis mucosa, submucosa, muscularis externa showed the intestinal wall was unaffected in Figure IX.

Cross section of the large intestine of rats given $1.3 \mathrm{ml}$ (high dose) of aspartame for the first 3 weeks and on the fourth week, $2.5 \mathrm{ml}$ (high dose) of ethanolic extract of Moringa oleifera seed revealed inflammation of goblet cells and intestinal glands, showed the intestinal wall was also severely affected in Figure XI.

Cross section of the large intestine of rats given $1.5 \mathrm{ml}$ (high dose) of aspartame for the first three weeks and on the fourth week, $3.0 \mathrm{ml}$ (high dose) of nHexane extract of Moringa oleifera seed revealed intact absorptive columnar epithelium, goblet cells, intestinal gland, lamina propria, showed the intestinal wall was unaffected in Figure XIII.
Cross section of the large intestine of rats given $1.4 \mathrm{ml}$ (high dose) of aspartame followed by 2.8 $\mathrm{ml}$ (high dose) of ethanolic extract of Moringa oleifera seed for four weeks revealed atrophy of absorptive columnar epithelium, goblet cells and intestinal glands, thus indicating a severe effect on the intestinal wall in Figure XV.

Cross section of the large intestine of rats given $1.3 \mathrm{ml}$ (high dose) of aspartame followed by 2.5 $\mathrm{ml}$ (high dose) of n-Hexane of Moringa oleifera seed for four weeks revealed intact absorptive columnar epithelium, goblet cells and intestinal glands, showed the intestinal wall was unaffected in Figure XVII.

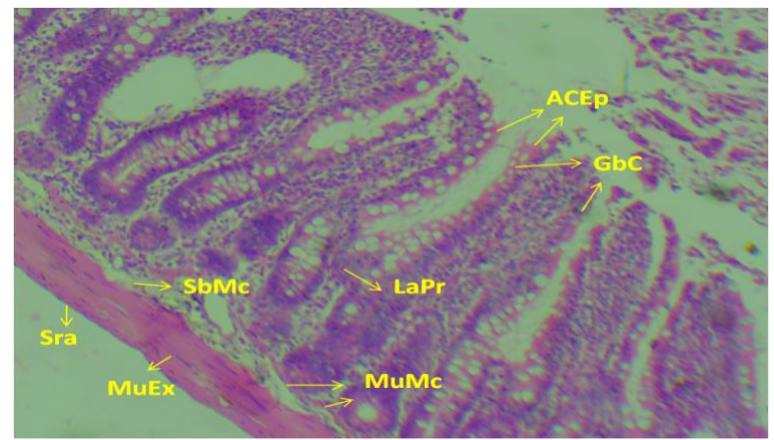

Figure I: Cross section of the large intestine of adult male albino Wister rat given distilled water. Group A (Control). (H\&E method, X100). Section revealed features typical of normal large intestine, absorptive columnar epithelium (ACEp), goblet cells (GbC) lamina propria (LaPr), muscularis mucosa (MuMc), submucosa (SbMc), muscularis externa (MuEx), serosa (Sra)

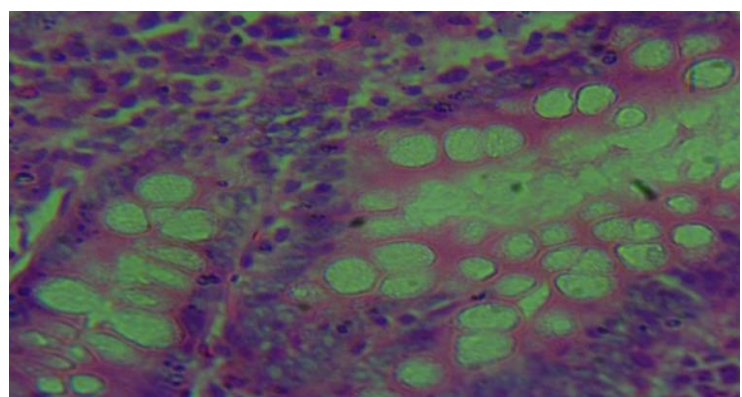

Figure II: Cross section of the large intestine of adult male albino wistar rat given distilled water. Group A (Control). (H\&E method, X400)

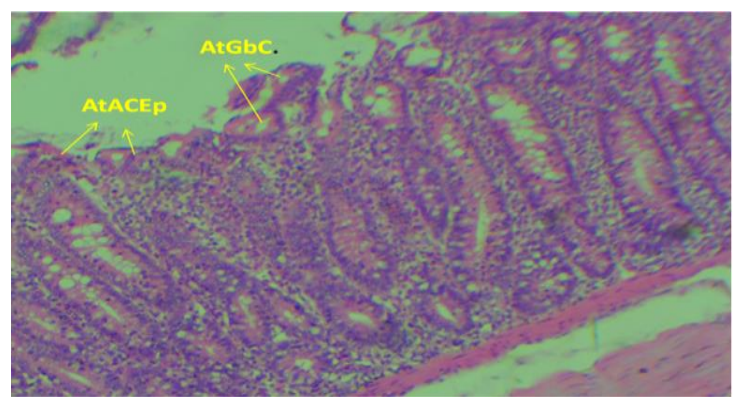

Figure III: Cross section of the large intestine of adult male albino wistar rat given $0.4 \mathrm{ml}$ (low dose) aspartame for 4 weeks

(28 days). Group B. (H\&E method, X100). Section revealed atrophy of absorptive columnar epithelium (At ACEp), atrophy of goblet cells (AtGbC). Inference: slightly affected 


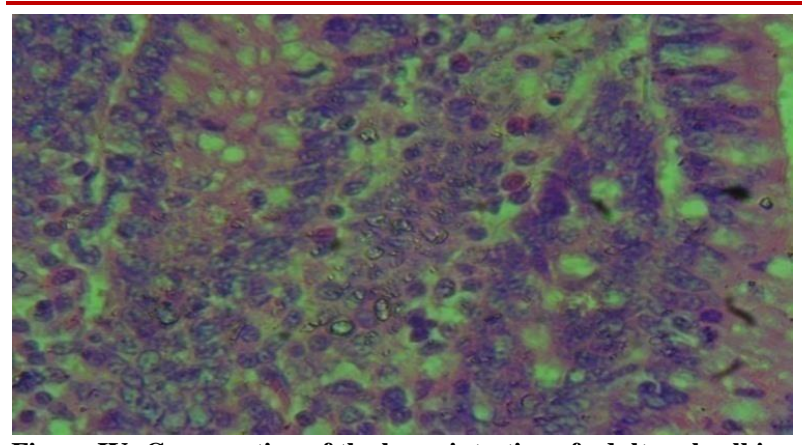

Figure IV: Cross section of the large intestine of adult male albino wistar rat given $0.4 \mathrm{ml}$ (low dose) aspartame for 4 weeks ( 28 days). Group B. (H\&E method, X400). Section revealed atrophy of absorptive columnar epithelium (AtACEp), atrophy of goblet cells (AtGbC)

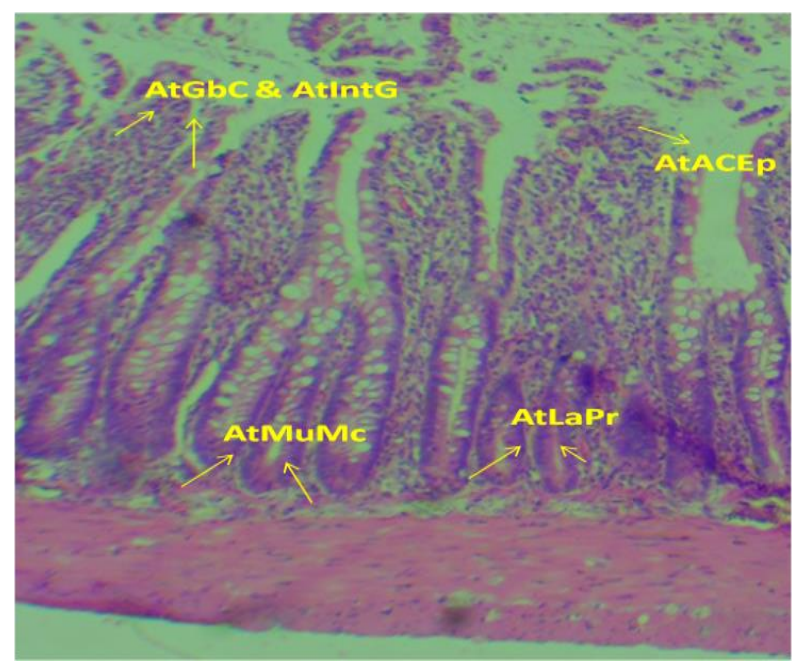

Figure V: Cross section of the large intestine of adult male albino wistar rat given $1.5 \mathrm{ml}$ (high dose) aspartame for 4 weeks (28 days). Group C. (H\&E method, X100). Section revealed: Atrophy of absorptive columnar epithelium (AtACEp), atrophy of goblet cells (AtGbC), atrophy of intestinal glands (AtIntG)), atrophy of lamina propria (AtLaPr), atrophy of muscularis mucosa (AtMuMc), Inference: severely affected

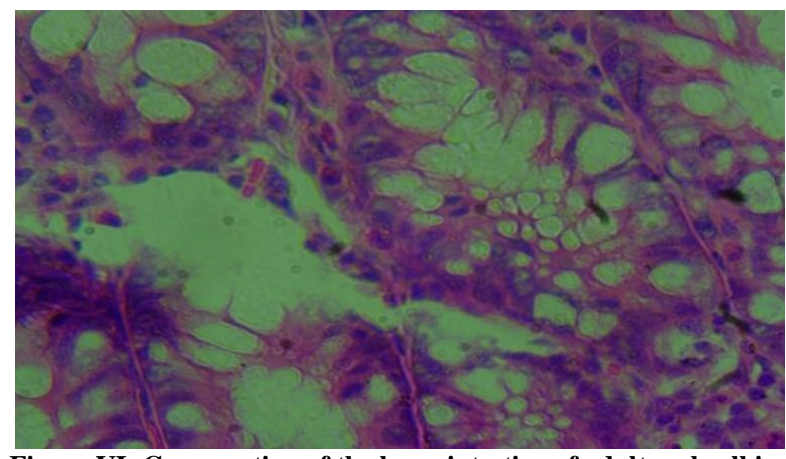

Figure VI: Cross section of the large intestine of adult male albino wistarrat given $1.5 \mathrm{ml}$ (high dose) aspartame for 4 weeks (28 days). Group C. (H\&E method, X400). Section revealed: Atrophy of absorptive columnar epithelium (AtACEp), atrophy of goblet cells (AtGbC), andatrophy of intestinal glands (AtIntG), atrophy of laminar propia (AtLaPr), atrophy of muscularis mucosa (AtMuMc). Inference: severely affected

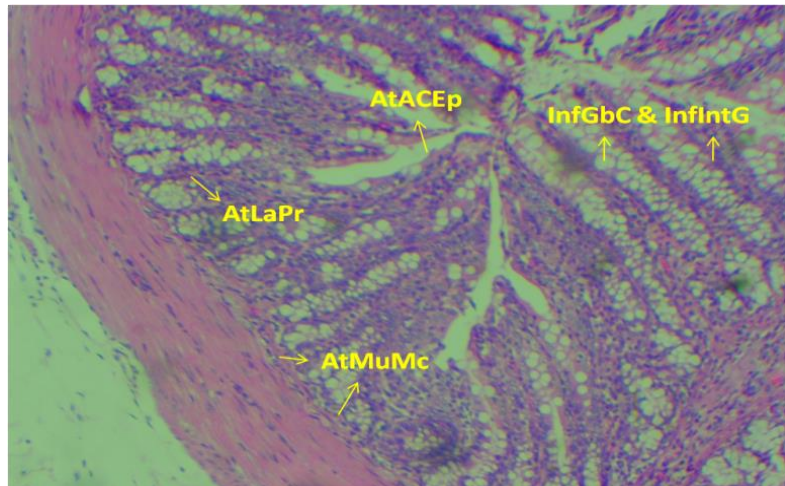

Figure VII: Cross section of the large intestine of adult male albino Wister rat given $0.6 \mathrm{ml}$ (low dose) aspartame for the first 3 weeks and on the fourth week, $1.5 \mathrm{ml}$ (low dose) ethanolic extract of Moringa oleifera seed only. Group D1.(H\&E method, X100). Section revealed: Atrophy of absorptive columnar epithelium (AtACEp), Inflammation of goblet cells (InfGbC), andinflammationof intestinal glands (InfIntG), atrophy of laminapropria (AtLaPr), atrophy of muscularis mucosa (AtMuMc). Inference: severely affected

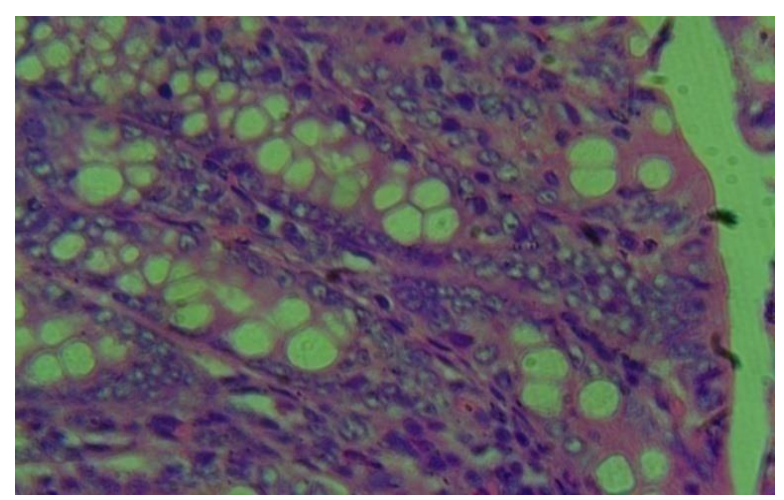

Figure VIII: Cross section of the large intestine of adult male albino Wister rat given $0.6 \mathrm{ml}$ (low dose) aspartame for the first 3 weeks and on the fourth week, $1.5 \mathrm{ml}$ (low dose) ethanolic extract of Moringa oleifera seed only. Group D1. (H\&E method, X400)

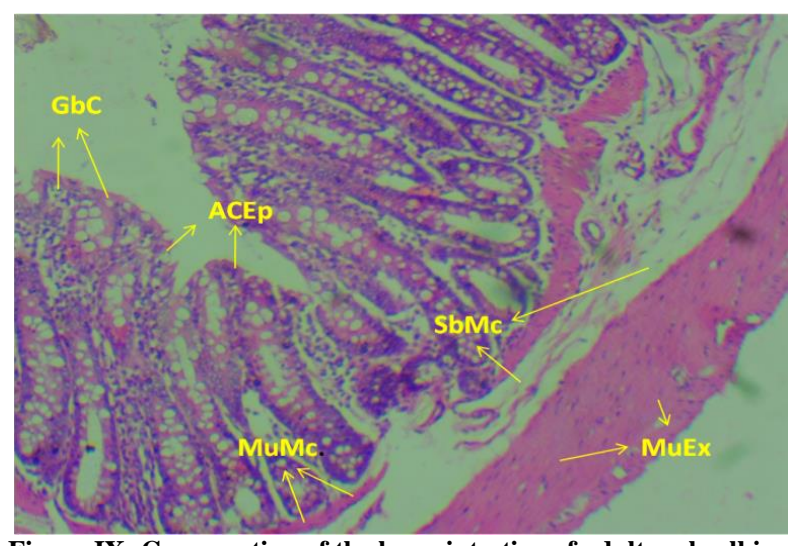

Figure IX: Cross section of the large intestine of adult male albino Wister rats given $0.5 \mathrm{ml}$ (low dose) aspartame for the first 3 weeks and on the fourth week, $1.3 \mathrm{ml}$ (low dose) $\mathrm{n}$-Hexane extract of Moringa oleifera seed only. Group D2. (H\&E method, X100).

Section revealed intact: Absorptive columnar epithelium (ACEp), goblet cells (GbC),muscularis mucosa (MuMc), submucosa (SbMc), muscularis externa (MuEx). Inference: unaffected 


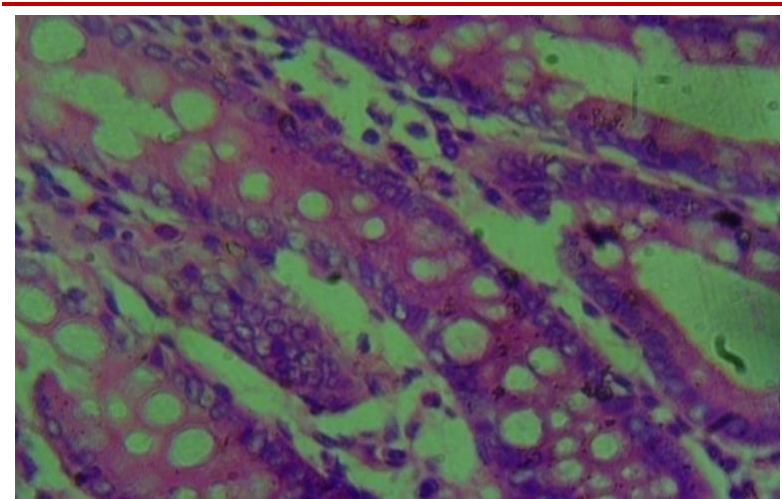

Figure X: Cross section of the large intestine of adult male albino Wister rats given $0.5 \mathrm{ml}$ (low dose) aspartame for the first 3 weeks and on the fourth week, $1.3 \mathrm{ml}$ (low dose) n-Hexane extract of Moringa oleifera seed only. Group D2. (H\&E method, X400)

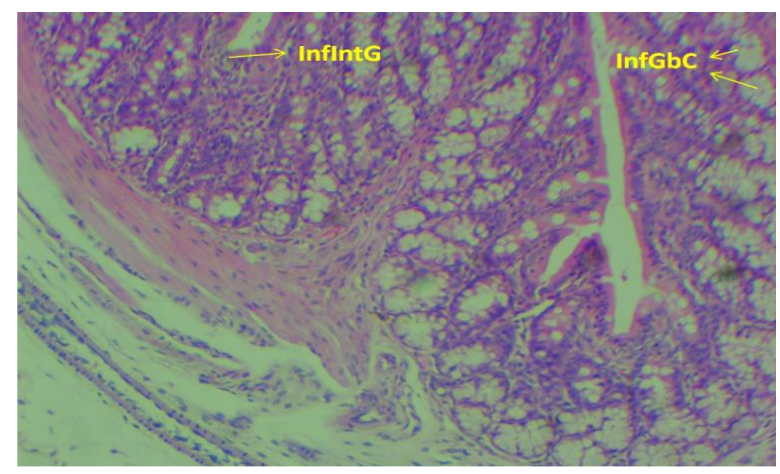

Figure XI: Cross section of the large intestine of adult male albino Wister rats given $1.3 \mathrm{ml}$ (high dose) aspartame for the first 3 weeks and on the fourth week, $2.5 \mathrm{ml}$ (high dose) ethanolic extract of Moringa oleifera seed only. Group E1. (H\&E method, X100). Section revealed: Inflammation of goblet cells (InfGbC), and inflammation of intestinal glands (InfIntG).Inference: slightly affected

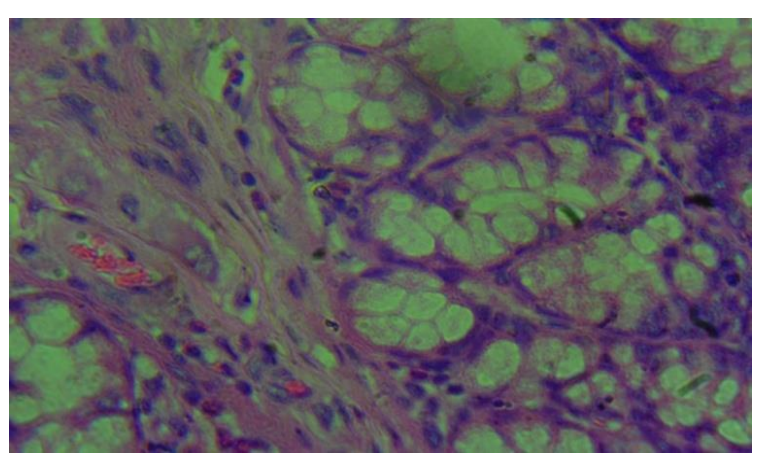

Figure XII: Cross section of the large intestine of adult male albino Wister rats given $1.3 \mathrm{ml}$ (high dose) aspartame for the first 3 weeks and on the fourth week, $2.5 \mathrm{ml}$ (high dose) ethanolic extract of Moringa oleifera seed only. Group E1. (H\&Emethod, X400)

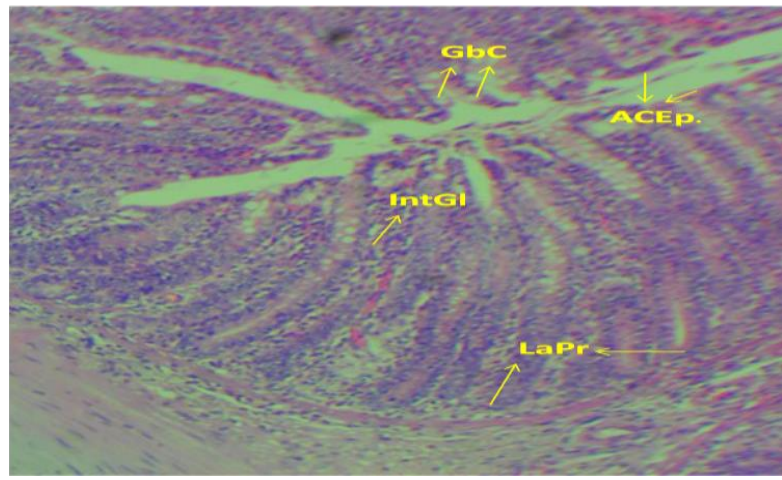

Figure XIII: Cross section of the large intestine of adult male albino Wister rats given $1.5 \mathrm{ml}$ (high dose) aspartame for the first 3 weeks and on the fourth week, $3.0 \mathrm{ml}$ (high dose) n-Hexane extract of Moringa oleifera seed only. Group E2. (H\&E method, X100). Section revealed intact: Absorptive columnar epithelium (ACEp), goblet cells (GbC), Intestinal glands (IntGl), lamina propria(LaPr). Inference: unaffected

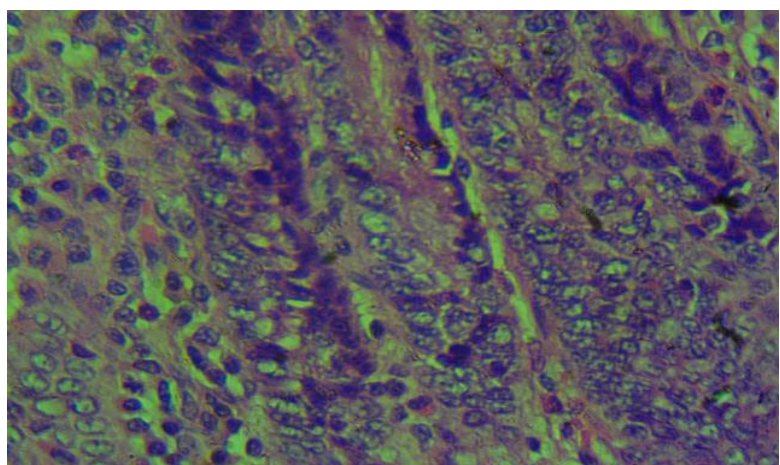

Figure XIV: Cross section of the large intestine of adult male albino Wister rats given $1.5 \mathrm{ml}$ (high dose) aspartame for the first 3 weeks and on the fourth week, $3.0 \mathrm{ml}$ (high dose) $\mathrm{n}$-Hexane extract of Moringa oleifera seed only. Group E2. (H\&E method, X400

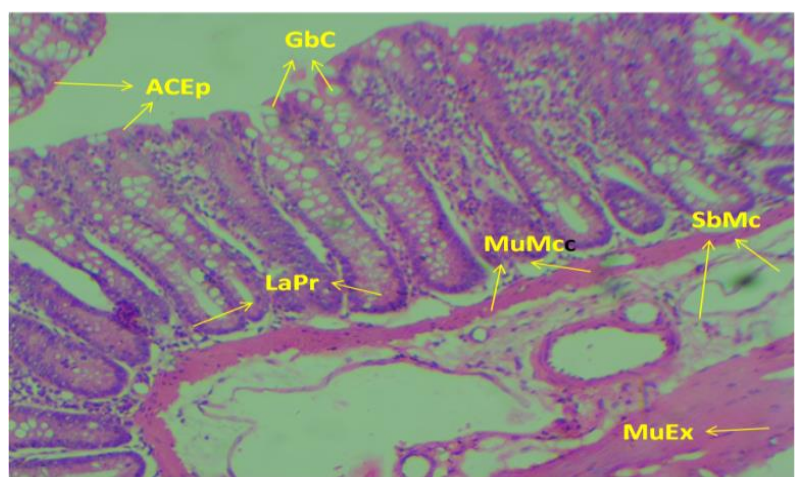

Figure XV: Cross section of the large intestine of adult male albino Wister rats given rats given $1.4 \mathrm{ml}$ (high dose) aspartame followed by $2.8 \mathrm{ml}$ (high dose) ethanolic extract of Moringa oleifera seed for four weeks. Group F1. (H\&E method, X100). Section revealed: Atrophy of Absorptive columnar epithelium (AtACEp), atrophy of goblet cells

(AtGbC), atrophy of intestinal glands (AtIntGl). Inference: severely affected 
Mbadugha Christopher Chiedozie et al; Sch Int J Anat Physiol, Jan., 2022; 5(1): 15-24

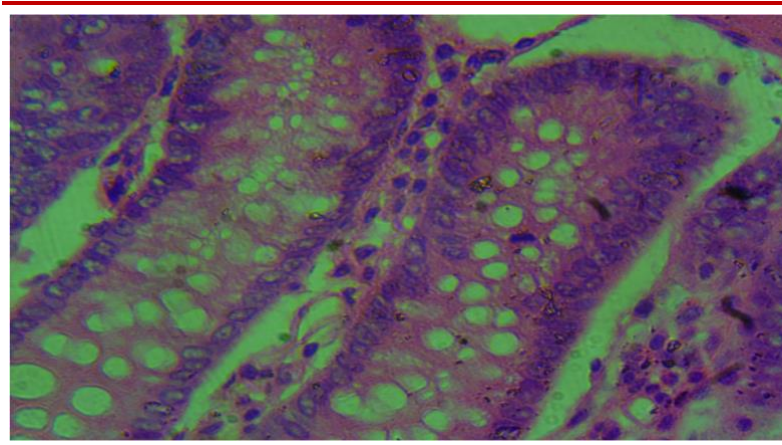

Figure XVI: Cross section of the large intestine of adult male albino Wister rats given rats given $1.4 \mathrm{ml}$ (high dose) aspartame followed by $2.8 \mathrm{ml}$ (high dose) ethanolic extract of Moringa oleifera seed for four weeks Group F1. (H\&E method, X400)

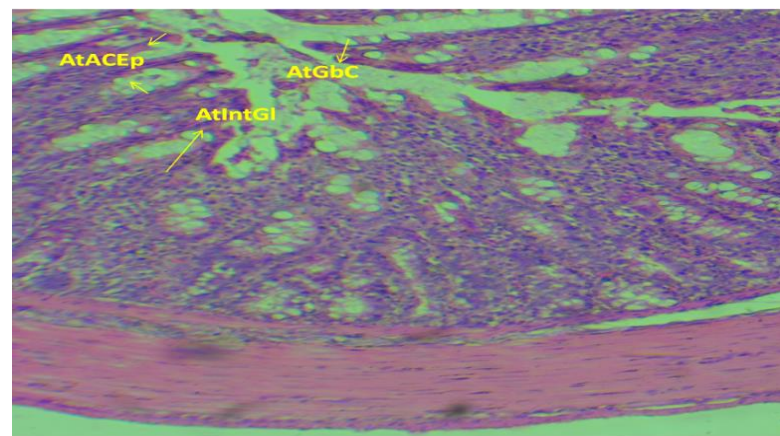

Figure XVII: Cross section of the large intestine of adult male albino Wister rats given $1.3 \mathrm{ml}$ (high dose) aspartame followed by $2.5 \mathrm{ml}$ (high dose) $\mathrm{n}$-Hexane extract of Moringa oleifera seed for four weeks. Group F2. (H\&E method, X100). Section revealed intact: Absorptive columnar epithelium (ACEp), goblet cells (GbC), Intestinal glands (IntGl), laminapropria(LaPr), muscularis mucosa (MuMc), submucosa(SbMc) muscularisexterna (MuEx). Inference: unaffected

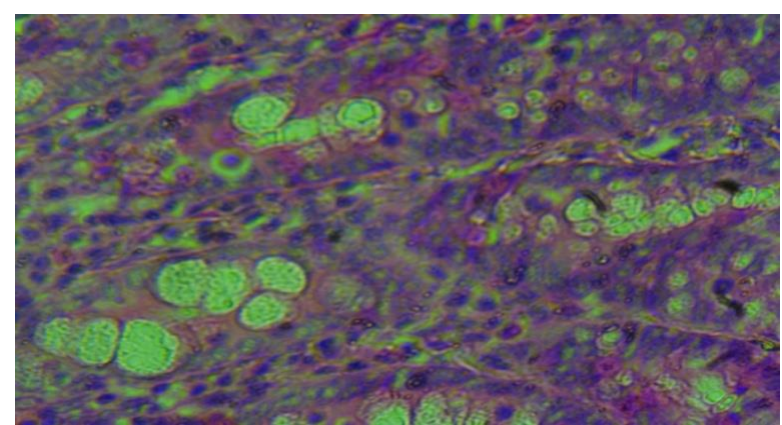

Figure XVIII: Cross section of the large intestine of adult male albino Wister rats given $1.3 \mathrm{ml}$ (high dose) aspartame followed by $2.5 \mathrm{ml}$ (high dose) $\mathbf{n}$-Hexane extract of Moringa oleifera seed for four weeks, Group F2. (H\&E method, X400)

\section{DISCUSSION}

There was observed steady and progressive increase in the weight of the rats in Group A (Control) as well as in the experimental groups. In the experimental groups, the rate of increase in weight is more appreciable in the groups treated with n- Hexane seed extract compared to the Ethanolic seed extract.
Ndonge et al, (2007), in their research using Moringa seed powder, suggested that the increase in weight may be due to the contents of the seed powder, specifically essential amino acids and vitamins $\mathrm{A}, \mathrm{B}, \mathrm{C}$ and $\mathrm{E}$; in addition, also suggested that antioxidants and antimicrobial compounds (phenols, tannins, alkaloids and cumarins) can act as growth promoters. Thus, in extrapolation of these suggestions to the outcome of our research using Ethanolic seed extract and N-Hexane seed extract, it may be deduced that some of these essential amino acids, vitamins, as well as antioxidants and antimicrobial compounds were lost during the course of Ethanolic extraction, hence, the rats administered $\mathrm{n}$-Hexane seed extract gaining appreciable weight in comparison to the rats administered Ethanolic seed extract.

The findings concerning the blood glucose count of adult male albino Wister rats administered aspartame, and subsequently administered Moringa oleiera seed extract, as shown in table 3, is consistent with the report of Gupta et al. (2012), who reported the outcome of in-vivo antidiabetic effects of methanolic extracts of Moringa oleifera pods in streptozotocin (STZ)-induced diabetic albino rats; in which diabetic rats were treated with 150 or $300 \mathrm{mg} / \mathrm{kg}$ of extract for 21 days and the antidiabetic effects were evaluated by measuring changes in biochemical parameters in serum and pancreatic tissue. The progression of diabetes was significantly reduced after treatment with the extract. In treated rats, both doses of extract induced a significant reduction in serum glucose, with concomitant increases in serum insulin and protein levels.

The histological findings in groups: $\mathrm{D}_{1}$ administered $0.6 \mathrm{ml}$ (low dose) of aspartame and $1.5 \mathrm{ml}$ (low dose) of ethanolic extract of Moringa oleifera seed, and $\mathrm{E}_{1}$ administered $1.3 \mathrm{ml}$ (high dose) of aspartame and $2.5 \mathrm{ml}$ (high dose) of ethanolic extract of Moringa oleifera seed; revealed atrophy of absorptive columnar epithelium, inflammation of goblet cells, inflammation of intestinal glands, atrophy of lamina propria, and atrophy of muscularis mucosa.

In contrast, the histological findings in groups: $\mathrm{D}_{2}$ administered $0.5 \mathrm{ml}$ (low dose) of aspartame and $1.3 \mathrm{ml}$ (low dose) of n-Hexane extract of Moringa oleifera seed, and $\mathrm{E}_{2}$ administered $1.5 \mathrm{ml}$ (high dose) of aspartame and $3.0 \mathrm{ml}$ (high dose) of n-Hexane extract of Moringa oleifera seed, revealed intact absorptive columnar epithelium, goblet cells, muscularis mucosa, submucosa and muscularis externa indicating that the $n$-Hexane extract protected the intestinal wall from the toxic effect of aspartame.

Moringa oleifera leaf extracts are reported to possess ahypo-cholesterolemic function. $\beta$-sitosterol and 4-[ $\alpha$-(L-rhamnosyloxy) benzyl $]-0-m e t h y l$ 
thiocarbamate (trans) are two important active substances presence in the leaf extracts of $M$. oleifera that exhibit cholesterol lowering activities. These compounds could reduce the intestine uptake of dietary cholesterol in rats. Furthermore, plasma cholesterol was decreased and fecal cholesterol was increased in rats fed with Moringa leaf extracts. In addition, another two components, moringine and moringinine, have been recently identified from $M$. oleifera leaves, which have roles in anti-hypoglycemic functions. The outcome of our research had suggested atrophy of absorptive columnar epithelium, inflammation of goblet cells, inflammation of intestinal glands, atrophy of lamina propria, and atrophy of muscularis mucosa, both in aspartame administered groups and ethanolic seed extract administered groups following aspartame administration. The implication is that the reported reduction in intestine uptake of dietary cholesterol in rats will not be feasible, because of the reported disruption of the intestinal morphological characteristics in these groups. Extract protected the intestinal wall from the toxic effect of aspartame.

In group $\mathrm{F}_{1}$ administered $1.4 \mathrm{ml}$ (high dose) of aspartame and $2.8 \mathrm{ml}$ (high dose) of ethanolic extract of Moringa oleifera seed, sections revealed atrophy of absorptive columnar epithelium, atrophy of goblet and intestinal glands, indicating that the ethanolic extract of Moringa oleifera could not protect the large intestine from aspartame toxicity. In group $\mathrm{F}_{2}$ administered 1.3 $\mathrm{ml}$ (high dose) of aspartame and $2.5 \mathrm{ml}$ (high dose) of n-Hexane extract of Moringa oleifera seed, sections revealed intact absorptive columnar epithelium, intestinal glands, lamina propia, muscularus mucosa, submucosa and muscularis externa, indicating that the n-Hexane extract protected the intestinal wall from the toxic effect of aspartame.

The statistical result of the blood glucose level as shown in Table 3 revealed significant changes in the blood glucose level of rats treated with high dose of aspartame and n-Hexane extract of Moringa oleifera seed. This is in line with a previous research carried out by Palmnäs et al., 2014.

\section{CONCLUSION}

The findings suggest enhanced surface epithelial protection with $\mathrm{n}$-Hexane Moringa oleifera seed extract from the toxic effect of aspartame.

\section{REFERENCES}

- Abhilash, M., Sauganth Paul, M. V., Varghese, M. V. and Nair, R. H. (2013).Long-term consumption of aspartame and brain antioxidant defense status. Drug and Chemical Toxicology, 36(2): 35-140

- Atreya, I., Atreya, R. and Neurath, M. F. (2008). $\mathrm{NF}-\kappa \mathrm{B}$ in inflammatory bowel disease, Journal of Internal Medicine, 263(6): 591-596.
- Azad, M. B., Abou-Setta, A. M., Chauhan, B. F., Rabbani, R., Lys, J., Copstein, L., Mann, A., Jeyarama, M. M., Reid, A. E., Fiander, M., Mackay, D. S., MacGavock, J., Wicklow, B. and Zarychanski, R. (2017). Nonnutritive sweeteners and cardiometabolic health: a systematic review and meta-analysis of randomized controlled trials and prospective cohort studies. Canadian Medical Association Journal, 189(28): 929-939.

- Berkovich L., Earon G., Ron I., Rimmon A., Vexler A. and Lev-Ari S. (2013). Moringaoleifera aqueous leaf extract down-regulates nuclear factorkappaB and increases cytotoxic effect of chemotherapy in pancreatic cancer cells. $B M C$ Complement and Alternative Medicine. 13: 212219.

- George, V., Arora, S., Wadhwa, B. K. and Singh, A. K. (2010). Analysis of multiple sweeteners and their degradation products in lassi by HPLC and HPTLC plates. Journal of Food Science and Technology, 47(4): 408-413.

- Ghasi S., Nwobodo E., Ofili J. (2000). Hypocholesterolemic effects of crude extract of leaf of Moringa oleifera Lam. in high-fat diet fed Wistar rats. J. Ethnopharmacol. 69:21-25. doi: 10.1016/S0378-8741(99)00106-3.

- Giner, E., And'ujar, I., Recio, M. C., R'10s, J. L., Cerd'a-Nicol'as, J. M. and Giner, R. M. (2011). Oleuropein ameliorates acute colitis in mice. Journal of Agricultural and Food Chemistry, 59(24): 12882-12892.

- Gupta R, Mathur M, Bajaj VK, Katariya P, Yadav S, Kamal R, et al. (2012). Evaluation of antidiabetic and antioxidant activity of Moringa oleifera in experimental diabetes. $J$ Diabetes. 4(2):164-71. doi: 10.1111/j.17530407.2011.00173.x.

- Humphries, P., Pretorius, E. and Naudé, H. (2008).Direct and indirect cellular effects of aspartame on the brain. European Journal of Clinical Nutrition, 62: 451-462

- $\quad$ Lutsey, P. L., Steffen, L. M. and Stevens, J. (2018). Dietary intake and the development of the metabolic syndrome: The Atherosclerosis Risk in community study. Circulation,117: 754-761

- Mofijur, M., Masjuki, H. H., Kalam, M.A., Atabani, A.E., Fattah, I.M.R. and Mobarak, H.M. (2014). Comparative evaluation of performance and emission characteristics of Moringaoleifera and Palm oil based biodiesel in a diesel engine. Industrial Crops and Product, 53: 78-84.

- $\quad$ Mohammed, A., Lai, O., Muhammad, S., Long, K. and Ghazali, H. (2003). Moringaoleifera, potentially a new source of oleic acid-type oil for Malaysia. Investigation and Innovation, 3: 137140.

- Nadeem, M. S., Kumar, V., Al-Abbasi, F. A., Kamal, M. A. and Anwar, F. (2020).Risk of 
colorectal cancer in inflammatory bowel Diseases. Seminars in Cancer Biology, 64: 51-60.

- Ndong M, Uehara M, Katsumate S, Suzuki K. (2007). Effects of oral administration of Moringa oleifera lam on glucose tolerance in Goto-Kakizaki and Wistar rats. J Clin Biochem Nutr. 40:229-233. doi: $10.3164 /$ jcbn.40.229.

- Nettleton, J. A., Lutsey, P. L., Wang, Y., Lima J. A. and Michos, E. D. (2019).Diet soda intake and risk of incident metabolic syndrome and type 2 diabetes in the Multi-Ethnic Study of Astherosclerosis (MESA).Diabetes Care. 32: 688694

- Ni, J., Wu, G. D., Albenberg, L. and Tomov, V. T. (2017). "Gutmicrobiota and IBD: causation or correlation. Nature Reviews Gastroenterology \& Hepatology, 14(10): 573-584.

- Odebiyi, O. O. and Sofowora, E. A. (1978). Phytochemicl screening of Nigerian Medicinal Plants Part II, IIoydia, 41: 1-25.
- Raja, R. R., Sreenivasulu, M., Vaishnavi, S., Navyasri, D. M., Samatha, G., and Geethalakshmi, S. (2016). Moringaoleifera - an overview.RA Journal of Applied Research, 2(9): 620-624.

- Rencüzogullari, E., Tüylü, B. A., Topaktaş, M., İla, H. B. (2004). Genotoxicity of Aspartame.Drug and Chemical Toxicology. 27(3): 257-268

- Sharma, V., Paliwal, R., Janmeda, P. and Sharma, S. (2012). Renoprotective effects of Moringaoleifera pods in 7, 12 dimethylbenz [a] anthracene exposed micsystem of Wistar albino rats. Chinese Journal of Integrative Medcine, 10: 1171-1178.

- Soxhlet, F. (1879). Die gewichts analytische Bestimmung des Milchfettes. Dinglers Polytecnisches Journal, 232: 461-465. 